\title{
The Living Constitution and the (Almost) Dead Contracts Clause
}

\author{
Thomas Halper*
}

\begin{abstract}
Under pressure to adapt to changing circumstances, the contract clause, though expressed in absolute terms, may now be violated for almost any reason at all. The living Constitution, in short, has virtually killed what was once a key constitutional provision.
\end{abstract}

\section{KEYWORDS}

Living Constitution; Contract Clause; Balancing Test; Home Building Association v. Blaisdell; Sveen v. Melin 
"No State shall . . . pass any ... Law impairing the Obligation of Contracts ..." -- United States Constitution, article I, section 10.

"We live by symbols," said Holmes, ${ }^{1}$ and so it is with the Constitution, ${ }^{2}$ which has been likened to a fetish. ${ }^{3}$ As Aristotle observed, "it is from metaphors that we can best get hold of fresh ideas." 4 They engage our imagination, highlighting similarities and pushing dissimilarities into the shadows. It is not surprising, then, that during ratification, the proposed Constitution was compared by its defenders to "the tree of life," "the federal chariot," ${ }^{, 6}$ and "the dazzling splendor of the sun." But for about a century, from the days of the early republic when a supporter described the Constitution as "the best national machine that is now in existence" till the late $19^{\text {th }}$ century, the prevailing constitutional metaphor compared it to a "machine that would go of itself," suggesting rational, impersonal efficiency. ${ }^{10}$ By this time, however, the machine began to be supplanted by the Darwinian notion ${ }^{11}$ of a living organism. ${ }^{12}$ For the Progressives, a dominant political force during this period, this meant, as Woodrow Wilson put it:

The Constitution cannot be regarded as a mere legal document, to be read as a will or contract would be. It must . . be a vehicle of life. As the life of the nation changes so must the interpretation of the document which contains its change ... by the exigencies and new aspects of life itself. ${ }^{13}$

1 Oliver Wendell Holmes, JR., The Collected Legal Papers 270 (Courier Corporation, 2012) (1920).

2 Edward S. Corwin, The Constitution as Instrument and as Symbol, 30 Am. PoL. SCI. Rev. 1071 (1936).

3 Max Lerner, Constitution and Court as Symbols, 46 YaLe L. J. 1290, 1294-1305 (1937). Henry Monaghan observed that Americans tend to believe that everything in the Constitution is good and that everything good is in the Constitution, notwithstanding widespread ignorance as to what it actually contains. Henry Paul Monaghan, Our Perfect Constitution, 56 N.Y.U. L. Rev. 353 (1981).

4 Aristotle, Rhetoric bk. III, at 1410b (Jonathan Barnes ed., W. Rhys Roberts trans., Princeton Univ. Press 1984) (c. 350 B.C.E.).

51 Ratification of the Constitution by the States: Virginia 19 (John P. Kaminski et al. eds., 1988) [hereinafter RCS: VIRGINIA 1].

62 Ratification of the Constitution by the States: Massachusetts 803 (John P. Kaminski et al. eds., 1998).

7 RCS: VIRGINIA 1, supra note 5, at 177. Opponents preferred different labels: "a political monster of absurdity," 3 Ratification of the Constitution by the States: Virginia 1310 (John P. Kaminski et al. eds., 1993); "a deadly serpent," 1 RATiFication OF THE Constitution by the States: Massachusetts 47 (John P. Kaminski et al. eds., 1997); "a Pandora's box," 1 Ratification of the Constitution by the States: New York 134 (John P. Kaminski et al. eds., 2003).

8 Jack Nips [John Leland], The Yankee Spy, in 2 American Political Writings DURING THE Founding ERA, 1760-1805, 971, 977 (Charles Shang Hyneman \& Donald S. Lutz eds., 1983) (1794).

96 James Russell Lowell, Writings 207 (1892).

10 Giuseppa Saccaro-Battisti, Changing Metaphors of Political Structures, 44 J. Hist. IDEAS 31, 34 (1983).

11 Herman G. Stelzner, Analysis by Metaphor, 51 Q. J. SPEECH 52 (1965).

12 Michael Kammen, A Machine that Would Go of Itself: The Constitution in American Culture, 17-20, 140-41, 177 (1986).

13 Woodrow Wilson, Constitutional Government in the United States 192 (1911). 
But it was not the Progressives who accounted for the triumph of the organic metaphor, but rather, as John Compton has demonstrated, Protestant Evangelicals. In his telling, the Constitution began as a secular document dedicated to restraining government interference with commerce and property rights, but was impelled toward flexibility by the rising Evangelicals' relentless opposition to alcohol and gambling, which courts could not ignore. Older doctrines limiting the states' police power were revised, and once it was established that these powers could be used to combat vice, the gate was open to other, more prosaic claims. ${ }^{14}$ Among those who took advantage of this development were the Progressives. Enchanted by the potential of technical experts utilizing the authority of government, they saw that organic language with its aura of the warm and the natural, could counter the cold remoteness of their plans.

The Constitution, it must be said, welcomed the metaphor, for many of its wordings, like the commerce clause, the take care clause, and the guarantee clause, are so cryptic as only to hint at their meanings. Even the apparently clear cut requirement that Presidents be at least age thirty-five has not seemed clear cut to everyone. ${ }^{15}$ Thus the very vagueness of many of the Constitution's provisions, including many important provisions, may mimic invitations to judicial improvisation. Absent this improvisation, how is the Constitution to remain au courant, for the amending process is so cumbersome that if left alone, the nearly 240 year old document might become a beautiful anachronism, what John Marshall called a "splendid bauble." 16

The result is a proliferation of living Constitution clichés. Holmes called provisions of the Constitution "organic, living institutions." ${ }^{17}$ Cardozo thought "A Constitution has an organic life." "18 "The Constitution, we cannot recall too often, is an organism," wrote Frankfurter. " "We are construing a living Constitution," said Powell. ${ }^{20}$ Beard declared that the "Constitution as practice is a living thing .... How could it be otherwise?"21 Perhaps, the living Constitution's chief judicial expositor was Justice William Brennan. In his concurring opinion in Abington Township School District v. Schempp (1963), involving a Pennsylvania law requiring Bible reading in public schools, he declared: "Whatever Jefferson or Madison would have thought of Bible reading ... in what few public schools existed in their day," 22 must give way to imperatives generated by the circumstances found in today's nation of compulsory education and a proliferation of religious denominations. "The genius of the Constitution," Brennan said elsewhere, "rests . . . in the adaptability of its great principles." 23

14 John W. Compton, The Evangelical Origins of the Living Constitution (2014).

15 Mark Tushnet, Principles, Politics, and Constitutional Law, 88 Mich. L. Rev. 49, 51 n.9 (1989).

16 McCulloch v. Maryland, 17 U.S. 316, 421 (1819).

17 Gompers v. United States, 233 U.S. 604, 610 (1914).

18 Browne v. City of New York, 241 N.Y. 96, 111 (1925).

19 Joseph Burstyn, Inc. v. Wilson, 343 U.S. 495, 518 (1952).

20 Rummel v. Estelle, 445 U.S. 263, 307 (1980).

21 Charles A. Beard, The Living Constitution, 185 Annals Am. Acad. Pol. \& Soc. Scr. 29, 31 (1936).

22 Sch. Dist. of Abington Twp., Pa. v. Schempp, 374 U.S. 203, 241 (1963).

23 William J. Brennan, Jr., The Constitution of the United States: Contemporary Ratification, 27 S. Tex. L. Rev. 433, 438 (1986). Similar statements are legion, see, e.g., 
The living Constitution may seem like simple common sense. However, recalling that common sense tells us that the world is flat, perhaps its endorsement is insufficient. Metaphors may be highly useful in illustrating points or clarifying explanations. But they involve using familiar words to mean something unfamiliar, and if cleverly used, may highjack the imagination, so that we notice only the targeted similarities and pass over the differences. The Constitution is a document, and thus obviously not literally living. Yet when the term is applied, we know what it means: that the Constitution will adapt to changing circumstances in society. Who can be against adaptation? The problem is that the passive voice disguises who does the adapting. If it is done by constitutional amendment, that is one thing. If it is done by a court, say, assuming a few years after Reconstruction that racial problems have basically been solved ${ }^{24}$ or that the then current economy required liberty of contract, ${ }^{25}$ it is quite something else. It is not simply that we disapprove of the results. We may also harbor reservations about the process, specifically, where unelected judges find the authority to undertake the adaption, overruling decisions taken by elected law makers. As Justice Gorsuch put it, "Our Founders deliberately chose a written constitution . . . because they wanted to fix certain things." Living Constitution advocates, he went on, believe "judges [should] make it up." ${ }^{26}$ Metaphors may be helpful, but like everything else, they have their limits. Consider the tale of the contract clause.

The indispensability of contracts derives from a pair of persistent facts. First, we can rarely achieve our purposes solely by our own efforts. We need the assistance of other people. Second, in an uncertain future, we cannot rely simply on informal agreements, but require the authority of the state to enforce them. Absent contracts enforced by the state, transaction costs would zoom, resulting in inefficiencies of such magnitude that it would be difficult to see how any significant commitment could succeed. Given these facts, the practical significance of contracts is hard to exaggerate.

In recognition of this, the contract clause was regarded by a prominent Framer as "the soul of the Constitution." ${ }^{27}$ The War for Independence had left widespread economic dislocation in its wake, and the fears generated by Shays' Rebellion of angry Massachusetts farmers were by no means gone. ${ }^{28} \mathrm{~A}$ particular problem was farm debt, which the law often treated harshly, which induced legislatures to pass laws to ease the farmers' pain, which led creditors at the Constitutional Convention to seek protection against state mandated repudiation of debts or alteration of payment methods. There was also the conviction that state abrogation of contracts

Weems v. United States, 217 U.S. 349, 373 (1910) (McKenna, J.); ROBERT H. JACKSON, The Struggle for Judicial Supremacy: A Study of a Crisis in American Power Politics 174 (1941).

24 Civil Rights Cases, 109 U.S. 3, 24-25 (1883).

25 Lochner v. New York, 198 U.S. 45 (1905).

26 Kyle Peterson, The High Court's Rocky Mountain Originalist, Wall St. J., Sept. 8, 2019, at A11.

27 Charles Pinckney, Speech on the Section Ten of Article One of the Federal Constitution, in 4 The Debates in the Several State Conventions on the Adoption of the Federal Constitution 333 (Jonathan Elliot ed., 2d ed.. 1901).

28 Michael J.G. Cain \& Keith L. Dougherty, Suppressing Shays' Rebellion: Collective Action and Constitutional Design under the Articles of Confederation, 11 J. THEORETICAL Pol. 233 (1999). 
had driven up the cost of borrowing, especially from a Europe already suspicious about investing in the new nation. Finally, there was the ethical rule: lenders are entitled to rely on the mortgagors' promise to repay.

The Framers' concern was not simply that individual, presumably wealthy creditors would be harmed by official indifference to contractual obligations, but that commercial growth and stability, generally, would be seriously undermined, with perhaps far reaching economic, social, and political implications. John Marshall, writing forty years later, recalled that state abuses "had become so great, so alarming, as not only to impair commercial intercourse, and threaten the existence of credit, but to sap the morals of the people, and destroy the sanctity of private faith." ${ }^{29}$ Certainly, fears about impairing contracts was among the main reasons delegates decided to replace the ineffectual Articles of Confederation with a new Constitution. ${ }^{30}$ Even an anti-Federalist, James Winthrop ("Agrippa"), agreed that "It shall be left to every state to make and execute its own laws, except laws impairing contracts, which shall not be made at all." 31 Yet the impairment of contracts attracted little debate in Philadelphia (perhaps because of "a consensus that required no voice" 32 ), and may well have been included in the Constitution as a result of the efforts of Gouverneur Morris, head of the convention's Committee of Style, whose open wording seemed to apply both to private and public contracts. ${ }^{33}$

The contract clause was tossed in the grab bag of restraints on the states that is article I, section 10. That old standby, The Federalist, ignored the clause, except where Madison declared that violations would be "contrary to the first principles of the social compact and to every piece of sound legislation," ${ }^{34}$ and Hamilton

29 Ogden v. Saunders, 25 U.S. 213, 355 (1827).

30 James W. Ely, JR., The Contract Clause: A Constitutional History 7-12 (2016). The Northwest Ordinance, the Articles' most prominent achievement, included a similar provision. See Denis P. Duffey, The Northwest Ordinance as a Constitutional Document, 95 Colum. L. Rev. 929 (1995); Matthew J. Festa, Property and Republicanism in the Northwest Ordinance, 45 ARIz. St. L. Rev. 409, 448-52 (2013).

31 The Complete Anti-Federalist 112 (Herbert J. Storing \& Murray Dry eds., 1981).

32 Stuart Bruchey, The Impact of Concern for the Security of Property Rights on the Legal System of the Early American Republic, 1980 WIs. L. Rev. 1135, 1142.

33 William Michael Treanor, Framer's Intent: Gouverneur Morris, the Committee of Style, and the Creation of the Federalist Constitution (Georgetown Law Faculty Pubs. \& Other Works, Working Paper No. 2163, 2019), https://ssrn.com/abstract=3383183. Morris thought that "property [was] the main object of society." 1 THE RECORDS OF THE Federal Convention of 1787, at 533 (Max Farrand ed., 1911).

34 The Federalist No. 44, at 282 (James Madison) (Clinton Rossiter ed., 1961). Yet apparently no such principles barred the central government from impairing the obligations of contracts. Indeed, article I, section 8 expressly grants Congress the power to "establish a uniform rule . . on the subject of bankruptcies throughout the United States," and this "includes the power to discharge the debtor from his contracts and liabilities. ..", Hanover Nat. Bank v. Moyses, 186 U.S. 181, 188 (1902) (Fuller, C.J.). A national bankruptcy policy, it was thought, would minimize the deleterious effect upon interstate commerce and comity among states. Michael W. McConnell, Contract Rights and Property Rights: A Case Study in the Relationship between Individual Liberties and Constitutional Structure, 76 CAL. L. Rev. 267, 286 (1988). Madison believed that "there is more danger of those [contract] powers being abused by the state governments than by the government of the United States," due to competing factions checking each other in the extended republic. 1 ANNALS OF Cong. 458 (1789) (Joseph Gales ed., 1834). 
feared that "Laws in violation of private contracts" might disrupt peaceful relations among the states. ${ }^{35}$ It was assumed, as James Wilson pointed out, that "retrospective interferences only are to be prohibited." ${ }^{36}$ Perhaps because of its murky history, not even early court decisions delve much into its roots.

Notwithstanding its problematic birth, the language of the provision is noteworthy for its categorical, absolute finality. There is no weasely modifier, like "unreasonable' in the Fourth Amendment or "excessive' in the Eighth. Indeed, other items in section 10 itself contain modifiers, when it bans states from laying imposts except when "absolutely necessary for executing its inspection laws" and from entering into agreements "with another state or with a foreign power, or engage in war, unless actually invaded or in such imminent danger as will not admit of delay" (emphasis added).

When placed against these deliberately vague terms, the unwavering nature of the contract clause is stunning. Intellectually, the basis for this may have been belief in a Lockean "natural right to the acquisition and use of property." ${ }^{37}$ Thus, it is not surprising that important early cases interpreted it rigidly. In the 1790s, Champion and Dickason v. Casey (1792) saw a federal circuit court in Rhode Island rely on the clause to invalidate a state law that granted a three year delay in repaying debts to a prominent merchant, who had fallen onto hard times. ${ }^{38}$ Moreover, Marshall was a forceful advocate for the clause. In Fletcher v. Peck (1810), upholding a corrupt state land grant rescinded by a Georgia constitutional amendment, he declared, "When ... a law is in its nature a contract, when absolute rights have vested under that contract, a repeal of that law cannot divest those rights." ${ }^{39}$ In New Jersey $v$. Wilson (1811), he ruled against a state repeal of a tax exemption for Indians. ${ }^{40}$ In Sturges v. Crowninshield (1819), he struck down a state bankruptcy law that discharged debtors from all liability, observing, "Any law which releases a part of this obligation must, in the literal sense of the word, impair it." ${ }^{41}$ In Green v. Biddle (1823), he found an effort to change a land title conveyed to the national government by a state in violation of the clause. ${ }^{42}$ And in Dartmouth College v. Woodward (1819), he wrote to uphold a college charter granted prior to independence by the English Crown against a legislative effort to replace it. ${ }^{43}$

Elbridge Gerry of Massachusetts sought to apply the clause to the national government as well, but could not even receive a second to his motion. 2 The Records of the Federal Convention of 1787, at 619 (Max Farrand ed., 1911).

35 The Federalist No. 7, at 65 (Alexander Hamilton) (Clinton Rossiter ed., 1961).

361 The Collected Works of James Wilson 158 (Kermit 1 . Hall \& Mark David Hall eds., 2007).

37 G. Edward White \& Gerald Gunther, The Marshall Court and Cultural Change, 1815-1835, at 597 (1988). On Locke, see John Locke, The Second Treatise OF GovernMENT 3-30 (John Wiedhofft Gough ed., 6th ed., 1956) (1690).

38 Patrick T. Conley, Jr., The First Judicial Review of State Legislation: An Analysis of the Rhode Island Case of Champion and Dickason v. Casey, 36 R. I. B. J. 5 (1987).

39 Fletcher v. Peck, 10 U.S. 87, 135-38 (1810).

40 New Jersey v. Wilson, 11 U.S. 164 (1811).

41 Sturges v. Crowninshield, 17 U.S. 122, 197 (1819).

42 Green v. Biddle, 21 U.S. 1 (1823).

43 Trustees of Dartmouth Coll. v. Woodward, 17 U.S. 518 (1819). 
Under Marshall's successor, Roger B. Taney, the clause was the most used provision for striking down state legislation. ${ }^{4}$ In Bronson v. Kinzie (1843), for example, it invalidated a pair of state laws that altered mortgage contracts, leaving them worthless, ${ }^{45}$ and in Planters Bank v. Sharp (1848), Justice Woodbury ruled that if "an act of the legislature ... impaired the obligation of any contract ... the clause in the Constitution ... expressly prohibiting a state from passing any such law has been violated." ${ }^{46}$ After the Civil War, Justice Strong announced that "[ $\left.\mathrm{t}\right] \mathrm{here}$ is no more important provision in the federal Constitution," ${ }^{47}$ Justice Miller thought it "one of the most beneficial provisions of the federal Constitution," ${ }^{48}$ Justice Shiras found that "No provision of the Constitution ... has received more frequent consideration by this Court," 49 and the renowned British legal anthropologist, Henry Maine, proclaimed that "there is no more important provision in the whole Constitution." ${ }^{50}$ The contract clause, worded as a stiff club, was stiffly interpreted: states were not free retroactively to interfere with the substance of contracts.

By the late 19th century, the nation was being transformed by industrialization, urbanization, and immigration, and in response to these tectonic shifts, the nature and scope of government was also changing. Also, the use of the corporation as a legal device to organize economic activity became much more prevalent, as its advantages became much more evident. As states and localities pushed the limits of their police powers, increasingly they encountered corporate contract clause obstacles, and increasingly, courts began siding with governments. In Stone v. Mississippi (1879), the Court approved a state's revocation of a charter to conduct lotteries, observing that "the legislature cannot bargain away the police power of a state." ${ }^{51}$ In Manigault v. Springs (1905), too, the Supreme Court said that "the interdiction of statutes impairing the obligation of contracts does not prevent the State from exercising such powers as are vested in it for the promotion of the common weal, or are necessary for the general good of the public, though contracts previously entered into between individuals may thereby be affected." 52 In other words, the police powers are "paramount to any rights under contracts between individuals," impair contractual obligations whenever they had a good reason." ${ }^{54}$ Can a state ban lotteries, making the tickets lawfully sold worthless? ${ }^{55}$ Can a state ban the sale

44 David P. Currie, The Constitution in the Supreme Court: The First Hundred YEARs, 1789-1888, at 210-11 (1985).

45 Bronson v. Kinzie, 42 U.S. 311 (1843).

46 Planters' Bank v. Sharp, 47 U.S. 301, 318 (1848).

47 Murray v. Charleston, 96 U.S. 432, 448 (1877).

48 Washington Univ. v. Rouse, 75 U.S. 439, 442 (1869).

49 Barnitz v. Beverly, 163 U.S. 118, 121 (1896).

50 Henry Sumner Maine, Popular Government 248 (1885).

51 Stone v. Mississippi, 101 U.S. 814, 817 (1879).

$52 \quad$ Manigault v. Springs, 199 U.S. 473, 480 (1905).

53 Id. at $480-81$.

54 David P. Currie, The Constitution in the Supreme Court: The Protection of Economic Interests, 1889-1910, 52 U. CHI. L. Rev. 324, 334-35 (1985). Ironically, in the same year, the Court announced a constitutional right to liberty of contract in Lochner v. New York, 198 U.S. 45 (1905). It had earlier spoken of the liberty in Allgeyer v. Louisiana, 165 U.S. 578, 589-91 (1897).

55 Stone, 101 U.S. at 817. 
of beer, making existing lawful contracts invalid? ${ }^{56}$ Yes and yes. As time passed, exceptions to the rigid text of the clause were added to accommodate workers' compensation ${ }^{57}$ and railway rates, ${ }^{58}$ and World War I saw an emergency excuse involving rent control that cancelled housing leases. ${ }^{59}$ The Court reasoned that police powers constituted the most basic argument for government itself, "the preservation of the public health and the public morals, and the protection of public and private rights, ${ }^{\prime 60}$ and thus had to take precedence over the contracts clause.

The Court, in short, balanced the benefits from protecting contracts against the benefits of safeguarding the police powers, and the police powers usually won. ${ }^{61}$ Unless the competing claims are of incontestably obvious different worth, however, balancing is less a test than a means for avoiding a test. The balancing metaphor has a wonderful pictorial clarity: we place different weights on a scale and determine the heavier simply by literally observing which side goes down. Legal balancing, however, is an entirely different exercise. Instead of dealing with weights of given pounds, judges subjectively assign imaginary weights to the competing arguments; instead of an impersonal force like gravity objectively answering the question as to which is "heavier," there is only the judge's hunch. Furthermore, the very act of balancing begs two questions. First, are the two highlighted claims the only claims worth considering. The contract clause, for example, promises benefits not only for creditors, but for society at large. Should courts, then, balance these two claims plus the state's claim? The task quickly becomes exceedingly complex. Second, balancing begs the question as to whether enforcing the ban against impairing contracts should depend upon its consequences, for the plain wording of the clause says nothing about this. Nonetheless, impelled by balancing tests, the conquest of the contract clause by the police powers seemed all but complete.

All earlier emergencies, save the Civil War, were put in the shade by the Great Depression, and it is here, in Home Building Association v. Blaisdell (1934), that the emergency excuse reappeared with a vengeance. The Minnesota Mortgage Moratorium Act, passed the previous year, redrew mortgage contracts in that state. If a property had been foreclosed, the mortgagor was given an extended period to make good on the loan and in the meanwhile, could remain in possession of the property, provided only that he pay market rent. It was obvious, as Blaisdell conceded, ${ }^{62}$ that the state had impaired the obligation of contracts on a massive scale. The question was whether the emergency excused it.

Chief Justice Hughes, writing for a narrow 5-4 majority, thought it did. A veteran of over a quarter century in public life as governor, secretary of state, and presidential candidate, Hughes approached the issue with an "instrumentalist perception that government is a tool for social betterment [and that] government

Bos. Beer Co. v. Massachusetts, 97 U.S. 25 (1878).

New York Cent. R. Co. v. White, 243 U.S. 188 (1917).

Portland Ry., Light \& Power Co. v. R.R. Comm'n of Oregon, 229 U.S. 397 (1913).

59 Marcus Brown Holding Co. v. Feldman, 256 U.S. 170 (1921). See also, RoBert M. Fogelson, The Great Rent Wars: New York, 1917-1929, at 229-54 (2013).

60 Stone v. Mississippi, 101 U.S. 814, 820 (1879).

61 See, e.g., Union Dry Goods Co. v. Georgia Pub. Serv. Corp., 248 U.S. 372 (1919), private contracts; St. Louis Poster Advert. Co. v. City of St. Louis, 249 U.S. 269 (1919), public contracts.

62 Blaisdell v. Home Bldg. \& Loan Ass'n, 189 Minn. 422, 424 (1933). 
and law were the agencies of progress. ${ }^{963}$ Public rights, for him, superseded private rights ${ }^{64}$ and as an associate justice years before, he had supported the states in contract disputes with utilities, railroads, and a manufacturer. ${ }^{65}$ "Contracts," he believed, "must be made subject to the law, and not vice versa." ${ }_{66}$

Hughes begins his Blaisdell opinion with "Emergency does not create state power. Emergency does not increase granted power . .." ${ }^{67}$ and then, comparing the Depression to a "great public calamity such as fire, flood, or earthquake," 68 concludes: "An emergency existed in Minnesota which furnished a proper occasion for the exercise of the reserved power of the state to protect the vital interests of the community." ${ }^{69}$ Without the extension, the mortgage market would collapse, and as many states had enacted similar legislation, the national mortgage market would also be affected. "The economic interests of the state may justify the exercise of its continuing and dominant protective power notwithstanding the interference with contracts." ${ }^{70}$ In other words, "The policy of protecting contracts against impairment presupposes the maintenance of a government by virtue of which contractual relations are worthwhile - a government which retains adequate authority to secure the peace and good order of society." 71

As for the Framers, Hughes, now an advocate of the living Constitution, simply rejects the notion that "what the provision of the Constitution meant to the vision of that day it must mean to the vision of our time." ${ }^{\prime 72}$ His point, as one pundit put

63 Governor on the Bench: Charles Evans Hughes as Associate Justice, 89 HaRv. L. Rev. 961, 963 (1976).

64 Charles Evans Hughes, Conditions of Progress in Democratic Government, 13, 20 (1910).

65 See, e.g., N.Y. Elec. Lines Co. v. Empire City Subway Sys., 235 U.S. 179 (1914); Louisville \& N.R.R. v. Garrett, 231 U.S. 298 (1913); Cumberland Glass Mfg. Co. v. DeWitt \& Co., 237 U.S. 447 (1915).

66 Governor on the Bench: Charles Evans Hughes as Associate Justice, supra note 63, at 988. In striking down the National Industrial Recovery Act the following year, he wrote, "Extraordinary conditions do not create or enlarge constitutional power." Schecter v. United States, 294 U.S. 495, 528 (1935). This time, he meant it.

67 Home Building \& Loan Ass'n v. Blaisdell, 290 U.S. 398, 425 (1934). He was also prone to interpreting regulations in ways conducive to government activism. For example, in Jones Nat'l Bank v. Yates, 240 U.S. 541 (1916), involving an insolvent bank and fraud allegations against its chief officers, Hughes upheld the convictions on the basis of an interpretation of a regulation that neither party anticipated.

68 Blaisdell, supra note 67, at 439.

69 Id. at 444.

$70 \quad I d$. at 437.

$71 I d$. at 435 . Hughes concedes in a footnote that the Court a century earlier refused to accept the emergency excuse in Bronson v. Kinzie, 42 U.S. 311 (1843) and McCracken v. Hayward, 43 U.S. 608 (1844), but concludes that neither case "is directly applicable to the question now before us" because "there was no provision, as in the instant case, to secure the mortgagee the rental value of the property during the extended period" of redemption. $I d$. at 432 .

72 Blaisdell, supra note 67, at 443 . At the same time, he declared that "we find no warrant for the conclusion that ... the founders of our government would have interpreted the clause differently had they had occasion to assume that responsibility in the conditions of the later day." Yet the economic depression following the peace treaty with Britain in 1783 was perhaps the most serious the nation faced until 1929, and the Framers plainly took it into account. 
it, was that "the Constitution was made for a changing society, and consequently to be adapted to the needs thereof; and social changes since 1789 make the type of emergency with which the Minnesota statute deals a matter of public concern." 73 On the other hand, many of the Framers, Hughes knew, were men of property and unsympathetic with debtors' pleas. How to reconcile the claims of the Depression with the intentions of the Framers? Ignore the intentions of the Framers.

Hughes also maintains that the contractual obligation to Blaisdell was not truly impaired because interest continued to run, rent was paid, and the mortgage would be serviced. ${ }^{74}$ In that sense, he would argue, the extension, far from impairing the contract, actually preserved it. Of course, this argument would be more persuasive with minor contractual alterations than with major ones, for a substantially modified contract really constitutes a new contract, in that important terms of the agreement have been unilaterally changed. Is it reasonable to expect legislatures to foreswear such major interference for all time, irrespective of changed circumstances? Hughes thought not.

However, as Justice Sutherland pointed out in his dissent, the point of the contract clause was to prevent exactly Minnesota's kind of policy response to emergencies. Where Hughes disregarded the Framers, Sutherland was impressed with their opposition to easy debtor relief; indeed, he noted that the Constitution was created in a time of economic hardship, when calls for debtor relief were widespread and insistent. " 75 "If the provisions of the Constitution be not upheld when they pinch as well as when they comfort, they may as well be abandoned," said. Blaisdell might not have anticipated the Depression, but the Framers certainly did. Sutherland's gratuitous prescription will strike many as heartless: "individual distress ... should be alleviated only by industry and frugality, not by relaxation of law." But for him, the overriding fact was that the clause "forbids state action under any circumstances, if it have the effect of impairing the obligation of contracts." The text was the beginning and end of the story.

Yet for Hughes, the half-acknowledged role of emergency echoed the contract law's traditional notion of duress. Obligations of a contract may be voided if the "manifestation of assent is induced by an improper threat by the other party that leaves the victim no reasonable alternative." 78 Or as Holmes phrased it, if the promisor is forced "to choose the lesser of two evils."

Edward S. Corwin, Moratorium Over Minnesota, 82 U. Penn. L. Rev. 311, 312 (1934).

Home Building \& Loan Ass'n v. Blaisdell, 290 U.S. 398, 425 (1934).

Id. at $454-57$.

$I d$. at 448. A critic conceded that, "so far as historical investigation is to be relied upon in such a matter he is unquestionably right." Corwin, supra note 73, at 312.

77 Blaisdell, supra note 74, at 473. Luther Martin had opposed including the clause in the Constitution because he thought it banned debtor relief by legislatures. 1 THE RECORDS OF the Federal Convention of 1787, at 533 (Max Farrand ed., 1911) at 172, 21415. Madison in Federalist 44 defended the clause as inspiring "a general prudence and industry, and giv[ing] a regular course to the business of society," and Marshall thought it "manifested a determination to shield [the people] and their property from the effects of those sudden and strong passions to which men are exposed." Fletcher v. Peck, 10 U.S. 87, 137-38 (1810).

78 Restatement (Second) of Contracts, § 175(1) (1981).

79 Union Pac. R. v. Pub. Svc. Com'n., 248 U.S. 67, 70 (1918). 
conceived in extreme terms "involving loss of life, mayhem or imprisonment," today matters are much looser, taking into account the circumstances of the parties, though the emergency excuse "remains largely unused." the existing Minnesota mortgage contracts, then, amount to abusively taking advantage of changed circumstances? No one suggested that the mortgage was an unreasonable bargain when entered into. Nor was it alleged that the mortgage terms were misrepresented or that the mortgagor was ignorant of the terms or in some way incompetent. Nor were both parties mutually mistaken about some material fact or was a claim of impossibility of performance raised. Both sides were fully autonomous when the contract was struck; the arrangement was not an "unduly one sided," ${ }^{82}$ unconscionable affair, though the mortgagor evidently underestimated the risk involved. It was simply that the Depression, unforeseen by all parties, threatened the mortgagor, rendering him vulnerable. The issue was not whether the contract was unenforceable or void, but rather whether a state could retroactively and substantially alter the contract. For Sutherland, the Constitution "does not mean one thing at one time and an entirely different thing at another time." ${ }^{83}$ For Hughes, however, the Depression altered the terms of the agreement. His focus, from first to last, was not on the individual mortgagor before him, but instead on the "use of reasonable means to safeguard the economic structure upon which the good of all depends." 84

Hughes' reading reflects the Constitution's failure to address emergencies. Apart from a brief statement in Article I, section 9 on suspending habeas corpus, the Constitution is silent on the subject. ${ }^{85}$ Emergencies demand action, which ordinarily translates into expanded government power. However, emergencies do not come cosmically announced, but instead are labels imposed on events by fallible and self interested persons. It is hard to deny that the Depression was an emergency or that the destruction of the mortgage market would not significantly have added to that emergency. For this reason, it was easy for Hughes to speak about the constitutional impact of emergencies without pausing to define the term. But the larger assumption, that emergencies somehow justify work-arounds of the Constitution, is much harder to defend. Indeed, in the famous Steel Seizure case, when President Truman plausibly argued that a wartime strike would constitute such an emergency, the Court refused to grant him that authority. ${ }^{86}$

Hughes' arguments would be more persuasive, had Blaisdell claimed that the statute deprived him of his property in violation of the Fourteenth Amendment's due process clause. Here, he would merely have had to show that Minnesota had

$80 \quad$ Restatement (Second) of Contracts, supra note 78.

81 Grace M. Giesel, A Realistic Proposal for the Contract Duress Doctrine, 107 W. VA. L. Rev. 443, 444 (2005).

82 Russell B. Korobkin, A "Traditional" and "Behavioral" Law-and-Economics Analysis of Williams v. Walker-Thomas Furniture Company, 26 U. Haw. L. Rev. 444, 467 (2004).

83 Home Building \& Loan Ass'n v. Blaisdell, 290 U.S. 398, 449 (1934).

$84 \quad I d$. at 442.

85 To deal with war or serious internal dissension, the Roman Republic's senate appointed dictators "freed from all constitutional restraints" to serve for six month terms. By the second century B.C.E, the practice "was quietly abandoned but not abolished." Robert J. Bonner, Emergency Government in Rome and Athens, 18 ClassiCal J. 144, 146, 147 (1922).

86 Youngstown Sheet \& Tube v. Sawyer, 343 U.S. 579 (1952). 
a rational basis for its action. But presumably the contract clause cannot simply duplicate a dimension of the due process clause, for this would render it superfluous. The contract clause's absolute language suggests that it does, in fact, have a different and stronger meaning. But after Blaisdell, it is exceedingly difficult to say what it is. Hughes also declined to argue that since judicially ordered moratoriums were considered acceptable, legislative ordered moratoriums should also be permitted; indeed, as legislatures are democratically elected, their position might be even stronger than that of judges.

There is also the public policy defense, which has been traced to the English common law of the fourteenth century ${ }^{87}$ Simply put, a contract counter to an act of Parliament may not be enforced. This position makes sense, given the presumption of parliamentary supremacy, but in the United States no such presumption exists. Here, the claim that legislatures may retroactively cancel contracts would obviously leave the contract clause in tatters.

If we venture to ask how the Court decided as it did, instead of pursuing the usual why, another rationale suggests itself. While the notorious four Horsemen Sutherland, Butler, Van Devanter, and McReynolds - evidently felt no pressure to bend to the exigencies of the Depression, the majority did. Was this from policy conviction? A fear that a stubbornly negative Court might undermine its crucial nonpolitical image? It is impossible to say. But Blaisdell is hardly the only instance involving the Court, where nonlegal considerations apparently carried the day. In Bolling v. Sharpe (1954), for example, the Court treated the Fifth Amendment's due process cause as equivalent to the Fourteenth Amendment's equal protection clause. But because the Fifth Amendment's due process clause repeats the Fourteenth Amendment's due process clause, the equal protection clause, on this reading, becomes completely unnecessary. The Court nonetheless embraced this rather bizarre result because "it would be unthinkable that the same Constitution would impose a lesser duty on the federal government." ${ }^{88}$ It could hardly ban legally required racial segregation everywhere, except the nation's capital, where the Court itself sat.

It has been widely assumed that Blaisdell, a high profile case that seemed to treat the contract clause like a crasher at a wedding, signaled an end to its viability. But as David F. Forte has shown, ${ }^{89}$ this bit of conventional wisdom was refuted by a unanimous decision handed down only a few months later, Worthen $v$. Thomas. Thomas owed Worthen rent, and a court ordered him to pay $\$ 1200$. Thomas then died, leaving a $\$ 5000$ insurance policy for his wife. Worthen sought to garnish the insurance money to satisfy the debt, but the state enacted a statute that exempted insurance proceeds from garnishment. Worthen sued, claiming that the law unconstitutionally impaired his contract with Thomas.

Hughes, in ruling for Worthen, struggled to distinguish the case from Blaisdell. The emergency excuse, he wrote, "must be limited by reasonable conditions appropriate to the emergency." $"{ }^{0}$ But the law in question made no distinctions. "There is no limitation of amount, however large. Nor is there any limitation as to

\footnotetext{
87 Percy H. Winfield, Public Policy in the English Common Law, 42 Harv. L. Rev. 76, $77-$ 78 (1928).

88 Bolling v. Sharpe, 347 U.S. 497, 500 (1954).

89 David F. Forte, Forgotten Cases: Worthen v. Thomas, 66 Clev. St. L. Rev. 705 (2018).

90 W. B. Worthen Co. v. Thomas, 292 U.S. 426, 433 (1934).
} 
beneficiaries ... There is no restriction with respect to particular circumstances or relations." ${ }^{91}$ Blaisdell met this test; Worthen did not. Sutherland and the three other horsemen concurred, again insisting, "We were unable then [in Blaisdell], as we are now, to concur in the view that an emergency can ever justify . . . a nullification of a constitutional restriction upon state power in respect of the impairment of contractual obligations." ${ }^{92}$ In Worthen v. Kavanaugh ${ }^{93}$ and Treiglee v. Acme Homestead Association, decided over the next two years, the Court unanimously followed in the Worthen v. Thomas path. ${ }^{94}$ Perhaps, the contract clause was not moribund after all.

This impression was reinforced in Wood v. Lovett (1941), where a state repealed a law passed two years earlier that guaranteed clear title to land, curing tax irregularities, with the purpose of increasing tax collections. The Supreme Court overturned the law. Justice Roberts conceded that the states and the federal government were facing a financial crisis, but thought that the "acts of the state in depriving the taxpayer of the right to set aside a sale for technical procedural defects" $" 95$ qualified as impairing the obligation of contracts.

But it was a long dissent in Wood by Justice Black that before long was to become judicial orthodoxy. Black began by discussing the severe economic emergency that led to the legislation, declaring that it was the "imperative duty" of policymakers to act, and finding the law a "rational and understandable" response ${ }^{96}$ that resembled Minnesota's in Blaisdell. ${ }^{97}$ "The Blaisdell decision," he said, "represented a realistic appreciation of the fact that ours is an evolving society and that the general words of the contract clause were not intended to reduce the legislative branch of government to helpless impotency." ${ }^{98}$ In East New York Savings Bank v. Hahn (1945), the Court adopted Black's views, expressly denying that an emergency excuse was required to rein in the contract clause. ${ }^{99}$ The Black view prevailed for nearly thirty years, leaving the contract clause with "virtually no legal effect,"100 "a pale shadow of its former self."101

In United States Trust Co. of New York v. New Jersey (1977), the Court surprisingly took a more aggressive view. The case involved bonds of the Port Authority of New York and New Jersey. Bond holders had been told that bond money would not go to subsidize passenger rail service; in the midst of a highly publicized oil crisis, the state repealed the provision, making bond money available for that purpose. A bond holder sued, and the Supreme Court, noting that other

Id. at 431 .

Id. at 434 .

A.L.A. Schechter Poultry Corp. v. United States, 295 U.S. 495 (1935).

94 Treigle v. Acme Homestead Assn., 297 U.S. 189 (1936).

95 Wood v. Lovett, 313 U.S. 362, 371 (1941).

96 Id. at 374.

$97 \quad$ Id. at 377.

98 Id. at 384. Black, famous for his textual literalness in free speech, here opted for a freewheeling approach.

99 E. N.Y. Sav. Bank v. Hahn, 326 U.S. 230, 235 (1945).

100 Forte, supra note 89, at 722 ("all that re-mains of the Contract Clause's protective sweep is an asymmetric middle-tier test that has little analytic benefit and virtually no legal effect").

101 Thomas W. Merrill, Public Contracts, Private Contracts, and the Transformation of the Constitutional Order, 37 CaSe W. Res. L. Rev. 596, 598 (1987). 
alternatives could have been chosen, ruled that the repeal violated the contract clause. The Court distinguished between private and public contracts. Private contracts would receive cursory review, but because public contracts involved the "state's self-interest" - the state enacted the law that permitted it to escape an obligation - here the "Contract Clause would provide no protection at all."102 As the Court said a few years later, "When a state itself enters into a contract, it cannot simply walk away from its financial obligations." 103 Of course, the idea that private contracts deserve less scrutiny is exactly the opposite of the view prevailing in the Framers' generation. ${ }^{104}$

In 1978 in Allied Structural Steel Co. v. Spannaus, the Court struck down a law that altered the terms of a pension benefit plan. In response to the denuding of the clause, Justice Stewart wrote, "If the contract Clause is to retain any meaning at all, ... it must be understood to impose some limits upon the power of a state to abridge existing contractual relationships, even in the exercise of its otherwise legitimate police power." ${ }^{\prime 105}$ Unlike United States Trust decided a year earlier, Allied Steel found private contracts to merit more scrutiny. ${ }^{106}$ Justice Brennan, dissenting, declared, "To permit this level of scrutiny of laws that interfere with contract based expectations is an anomaly." 107 As these two cases with their generous readings of the clause were exceptions to decades of rejecting such claims, Brennan, indeed, had a point. Would they have any progeny?

This brings us to Sveen v. Melin (2018), ${ }^{108}$ the Court's first contract clause case in over thirty years. Mark Sveen and his wife, Kaye Melin, were living in Minnesota, when he named her the primary beneficiary of his life insurance policy. His two adult children from his prior marriage were named contingent beneficiaries, and retained their status as primary beneficiaries of a second life insurance policy. Minnesota then in 2002 enacted a statute that would automatically revoke spousal beneficiary status after divorce and transfer it to the contingent beneficiaries, the couple divorced in 2007, and in 2011 Sveen died. Under the law, Sveen could have filed papers to retain Melin as his primary beneficiary, but he never acted nor did the divorce settlement address the question. Who gets the money? Did Minnesota impair the obligation of contracts?

Default rules were customary at common law to resolve intestate conflicts, and twenty-five other states had legislation similar to Minnesota's. The governing assumption was that the policy holder would prefer the revocation, but for some reason never acted to bring it about.

Justice Kagan, writing for an eight vote majority, began by observing that the "legal system has long used default rules to resolve estate litigation in a way that conforms to decedents' presumed intent," 109 adding that "not all laws affecting

102 U.S. Tr. Co. of New York v. New Jersey, 431 U.S. 1, 26 (1977).

103 Energy Reserves Grp., Inc. v. Kan. Power \& Light Co., 459 U.S. 400, $412-14$ (1983).

104 Douglas W. Kmiec \& John O. McGinnis, The Contract Clause: A Return to the Original Understanding, 14 HASTINGS Const. L. Q. 525, 532-33 (1987).

105 Allied Structural Steel Co. v. Spannaus, 438 U.S. 234, 242 (1978).

106 Id. at 244-45.

107 Id. at 261.

108 Sveen v. Melin, 138 S. Ct. 1815 (2018).

109 Id. at 1819. 
pre-existing contracts violate the [contract] clause." ${ }^{110}$ Laws modifying remedial processes raise no constitutional issues, but laws that invade the substance of contracts do. ${ }^{11}$ The test begins, she writes, by asking "whether the state law has operated as a substantial impairment of a contractual relationship." 112 The answer in Sveen is so obviously no that "we may stop after step one." ${ }^{113}$ First, Kagan says, the law "furthers the policyholders' . . typical" intent. Thus, instead of impairing the contract, it supports it. Second, the law likely does not disturb the policyholders' expectations because "an insured cannot reasonably rely on a beneficiary designation remaining in place after a divorce." 114 Third, policyholders retain the power to alter the default rule "with the stroke of a pen." 115 The minimal paperwork involved poses no constitutional problem.

Justice Gorsuch, dissenting, opens with some ridicule.

The Court's argument proceeds this way. Because people are inattentive to their life insurance beneficiary designations when they divorce, the legislature needs to change these designations retroactively to ensure they aren't misdirected. But because these same people are simultaneously attentive to beneficiary designations (not to mention the legislature's activity), they will surely undo the change if they don't like it. And even if that weren't true, it would hardly matter. People know that existing divorce laws sometimes allow courts to reform insurance contracts. So people should know a legislature might enact new laws upending insurance contracts at divorce. For these reasons, a statute rewriting the most important term of a life insurance policy — who gets paid—somehow doesn't "substantially impair" the contract. ${ }^{116}$

With Sveen, Gorsuch concedes that the law is valid if applied to policies bought after the law was passed, when there are no past contracts to impair. But if applied retroactively, it runs up against a flat constitutional prohibition against "any . . . law impairing the obligation of contracts" (emphasis added). ${ }^{117}$ The Framers could have offered loopholes, as they did elsewhere in section 10, but evidently chose not to.

Gorsuch then points to a loophole modern courts have devised allowing impairments in pursuit of "a significant and legitimate public purpose." $118 \mathrm{He}$ disapproves of the loophole, but even laying the disapproval aside, he notes that it has no relevance here. Factually, Gorsuch pointed to Melin's claim that Sveen intended to keep her as beneficiary, that there might be a number of plausible reasons for policyholders to retain their ex as beneficiary, and that in recognition of

\footnotetext{
10 Id. at 1821.

111 El Paso v. Simmons, 379 U.S. 497 (1965).

112 Sveen, supra note 108, at 1821-22.

113 Id. at 1822 . The second step would have inquired as to whether the law was drawn in an appropriate and reasonable way to advance a significant and legitimate public purpose.

114 Id. at 1823

115 Id.

116 Id. at 1826.

117 Id. at 1827.

118 Id.
} 
this, nearly half the states plus the federal government have not adopted automatic revocation. None of this information may be conclusive, he admits, but it does suggest that the state's "substantial impairment" is unreasonable; for it could have been avoided simply by requiring "courts to confirm that divorcing couples have reviewed their life insurance designations." Or Minnesota "could have instructed insurance companies to notify policyholders [or] required attorneys . . . to address the question with affected parties." Nor were these options not on the table, for women's rights organizations had long advocated them. "Yet there's no evidence Minnesota investigated any of them, let alone found them wanting." 119 As Kagan thought it plain that there was no impairment, Gorsuch believes the reverse. "It substantially impairs contracts by displacing the term that is the 'whole point' of the contract." 120 As he said elsewhere, "The Constitution's original public meaning supplies the key."121

A few recent cases suggest that, though enfeebled, the contract clause is not yet dead. In Elliott v. Board of Trustees of Madison Consolidated Schools (2017), ${ }^{122}$ the Seventh Circuit struck down a law that eliminated pre-existing layoff protection for tenured teachers, and in Association of Equipment Manufacturers v. Bergum (2019) ${ }^{123}$, the Eighth Circuit upheld a preliminary injunction enjoining a state regulation that impaired a pre-existing farm machinery contract without justification from a significant and legitimate public purpose. But cases like this are becoming vanishingly rare.

Sveen, then, represents the logical conclusion of a process that has left the contract clause eviscerated, like chicken on a butcher's table. The provision contains no vague modifier, but instead is plainly absolute in its meaning. It makes no mention of state police power nor offers exceptions for emergencies. It contains no invitation, implicit or explicit, to balance contractual interests against public or other interests. Nor does the clause distinguish between private and public contracts or even mention them. Justice Brennan was surely right that "there is nothing sacrosanct about a contract," 124 but did he mean there was nothing sacrosanct about the Constitution, either?

Of course, we are all familiar with the absolute that there are no absolutes. For example, we can quote Holmes' remark that "The most stringent protection of free speech would not protect a man in falsely shouting fire in a theatre and causing a panic." ${ }^{25}$ We can also make the banal observation that even a red light does not mean stop, if a police car's siren instructs us to go. And yet what these are, are exceptions that prove a rule. The presumption is in favor of the rule; exceptions have to be justified. As exceptions, they will be unusual. This is precisely the opposite of what has taken place with respect to the contract clause. Today, the exceptions are the rule. The question is not, as is typically the case in constitutional disputes, what the key words - "Impair," "obligation," or "contract" - mean. The Court makes no effort at the kind of Talmudic disquisition that Marshall famously

119 Id. at 1829.

120 Id. at 1830.

121 Oil States Energy Servs. v. Greene's Energy Grp., 138 S. Ct. 1365, 1381 (2018).

122 Elliott v. Bd. of Sch. Trustees of Madison Consol. Sch., 876 F.3d 926 (7th Cir. 2017).

123 Ass'n of Equip. Manufacturers v. Burgum, 932 F.3d 727 (8th Cir. 2019).

124 Allied Structural Steel Co. v. Spannaus, 438 U.S. 234, 261 (1978).

125 Schenck v. United States, 249 U.S. 47, 52 (1919). 
inflicted on "necessary." 26 Instead, it simply dispenses with the word "any," the anchor of the clause, through a kind of linguistic brute force. Thus, the contract clause today may be violated for almost any reason at all. The living Constitution, in short, has virtually killed a constitutional provision.

126 McCulloch v. Maryland, 17 U.S. 316, 413-15 (1819). 